\title{
Correction to: Effects of Root Zone Cooling on Butterhead Lettuce Grown in Tropical Conditions in a Coir-Perlite Mixture
}

\author{
Wan Fazilah Fazlil Ilahi ${ }^{1,2} \cdot$ Desa Ahmad ${ }^{1} \cdot$ Mohammud Che Husain $^{3}$
}

๑) Korean Society for Horticultural Science and Springer-Verlag GmbH Germany, part of Springer Nature 2018

\section{Correction to: Hortic. Environ. Biotechnol. 58(1):1-4. 2017. https://doi.org/10.1007/s13580-017-0123-3}

The original version of this article contained errors. The correct version should be written as shown in the following table.

\begin{tabular}{lll}
\hline No. & Before correction & After correction \\
\hline 1 & De Swaef T, Vermeulen K, & De Swaef T, Vermeulen K, \\
& Vergote N, Van Lommel J, & Vergote N, Van Lommel J, \\
Van Labeke MC, Bleyaert & Van Labeke MC, Bleyaert \\
P, Steppe K (2015) Plant & P, Steppe K (2015) Plant \\
sensors help to understand & sensors help to understand \\
tipburn in lettuce. 1099 Edi- & tipburn in lettuce. Acta Hor- \\
tion: International Society & tic. 1099:63-70 \\
for Horticultural Science & \\
(ISHS), Leuven, Belgium & \\
He J, Lee SK (1998) Growth & He J, Lee SK (1998) Growth \\
and photosynthetic charac- & and photosynthetic charac- \\
teristics of lettuce (lactuca & teristics of lettuce (Lactuca \\
sativa 1.) under fluctuating & sativa L.) under fluctuating \\
hot ambient temperatures & hot ambient temperatures \\
with the manipulation of & with the manipulation of cool \\
cool root-zone temperature. & root-zone temperature. J Plant \\
Journal of Plant Physiology & Physiol 152:387-391 \\
152(4):387-391 &
\end{tabular}

The original article can be found online at https://doi.org/10.1007/ s13580-017-0123-3.

\section{Wan Fazilah Fazlil Ilahi zahilah36@yahoo.com}

1 Department of Biological and Agricultural Engineering, Faculty of Engineering, Universiti Putra Malaysia, 43400 UPM Serdang, Selangor, Malaysia

2 Department of Agriculture Technology, Faculty of Agriculture, Universiti Putra Malaysia, 43400 UPM Serdang, Selangor, Malaysia

3 School of Bioprocess Engineering, University Malaysia Perlis, 02600 Arau, Perlis, Malaysia

\begin{tabular}{|c|c|c|}
\hline No. & Before correction & After correction \\
\hline$\overline{3}$ & $\begin{array}{l}\text { Lee SK, Cheong SC (1996) } \\
\text { Inducing head formation } \\
\text { of iceberg lettuce (lactuca } \\
\text { sativa } 1 \text {.) in the tropics } \\
\text { through root-zone tem- } \\
\text { perature control. Trop agric } \\
73: 34-42\end{array}$ & $\begin{array}{l}\text { Lee SK, Cheong SC (1996) } \\
\text { Inducing head formation } \\
\text { of iceberg lettuce (Lactuca } \\
\text { sativa L.) in the tropics } \\
\text { through root-zone tem- } \\
\text { perature control. Trop agric } \\
\text { 73:34-42 }\end{array}$ \\
\hline 4 & $\begin{array}{l}\text { Luo HY, Lee SK, He J } \\
\text { (2009) Integrated effects } \\
\text { of root-zone temperatures } \\
\text { and phosphorous levels } \\
\text { on aeroponically-grown } \\
\text { lettuce (lactuca sativa 1.) in } \\
\text { the tropics. Open Hortic J } \\
\text { 2:6-12 }\end{array}$ & $\begin{array}{l}\text { Luo HY, Lee SK, He J (2009) } \\
\text { Integrated effects of root-zone } \\
\text { temperatures and phospho- } \\
\text { rous levels on aeroponically- } \\
\text { grown lettuce (Lactuca sativa } \\
\text { L.) in the tropics. Open } \\
\text { Hortic J 2:6-12 }\end{array}$ \\
\hline 5 & $\begin{array}{l}\text { Ruter JM, Ingram DL (1990) } \\
\text { 14carbon labeled photo- } \\
\text { synthate partitioning in } \\
\text { ilex crenatarotundifolia'at } \\
\text { supraoptimal root-zone tem- } \\
\text { peratures. J Am Soc Hortic } \\
\text { Sci 115:1008-1013 }\end{array}$ & $\begin{array}{l}\text { Ruter JM, Ingram DL (1990) } \\
{ }^{14} \text { Carbon-labeled photo- } \\
\text { synthate partitioning in Ilex } \\
\text { crenata 'Rotundifolia' at } \\
\text { supraoptimal root-zone tem- } \\
\text { peratures. J Am Soc Hortic } \\
\text { Sci 115:1008-1013 }\end{array}$ \\
\hline 6 & $\begin{array}{l}\text { Stepowska AJ, Kowalczyk } \\
\text { W (2001) The effect of } \\
\text { growing media on yield } \\
\text { and nitrate concentration } \\
\text { in lettuce (lactuca sativa } \\
\text { var. Capitata 1.). } 548 \text { Edi- }\end{array}$ & $\begin{array}{l}\text { Stepowska AJ, Kowalczyk W } \\
\text { (2001) The effect of growing } \\
\text { media on yield and nitrate } \\
\text { concentration in lettuce (Lac- } \\
\text { tuca sativa var. Capitata } \mathrm{L} \text {.). } \\
\text { Acta Hortic. 548:503-510 }\end{array}$ \\
\hline
\end{tabular}

tion: International Society for Horticultural Science (ISHS), Leuven, Belgium

7 Udagawa Y, Ito T, Gomi K (1991) Effects of root temperature on the absorption of water and mineral nutrients by strawberry plants 'reiko' grown hydroponically. J Jpn Soc Hortic Sci 59:711-717 


\begin{tabular}{lll}
\hline No. & Before correction & After correction \\
\hline 8 & Yahya A, Shaharom AS, & Yahya A, Shaharom AS, \\
& Mohamad R, Selamat & Mohamad R, Selamat A \\
A (2009) Chemical and & (2009) Chemical and physical \\
physical characteristics of & characteristics of cocopeat- \\
cocopeat-based media mix- & based media mixtures and \\
tures and their effects on the & their effects on the growth \\
growth and development of & and development of Celosia \\
celosia cristata. Am J Agric & cristata. Am J Agric Biol Sci \\
Biol Sci 4:63-71 & $4: 63-71$ \\
\hline
\end{tabular}

